\title{
Studi Fenomenologi Interaksi Sosial Perempuan Bercadar di Media Sosial
}

\author{
Yusrina Zulfa, Ahmad Junaidi \\ yusrina.915150200@stu.untar.ac.id,ahmadd@fikom.untar.ac.id
}

Fakultas Ilmu Komunikasi Universitas Tarumanagara

\begin{abstract}
Veil in Arabic is the Niqab which means covering the face of the nose and used by Muslim women. Basic use of the veil is to keep so as not to attract the attention of men who are not mahram in Islam. The presence of veiled women are still not fully accepted by the people of Indonesia, which is also affected by several factors such as the radical movement in Indonesia who identified herself with a veil, giving rise to a negative stigma in the community. However, in today's digital development, social media as a secondary interaction media community with open receive option for veiled Muslim women. Among the negative stigma about the veil in the community, thus making the trend of veil became a commonplace thing in social media Instagram. So the focus of this research is how the process of social interaction of women veiled with virtual society who are actively using social media Instagram. The method used is qualitative descriptive with a Phenomenological approach, data collection methods using interview and observations non-participant. The conclusion of this research is the social media are different with the social interaction that happened in between the society itself. The social interaction that performed by veiled women in social media is in the tolerant accomodation form, so it avoids the conflict.
\end{abstract}

Keywords: Veiled Women, Social Media, Instagram, Social Interaction

\begin{abstract}
Abstrak
Cadar dalam bahasa Arab yaitu Niqab yang berarti penutup wajah dari batas hidung dan digunakan oleh perempuan muslim. Dasar penggunaan cadar adalah untuk menjaga agar tidak menarik perhatian laki-laki yang bukan mahram dalam Islam. Keberadaan perempuan bercadar masih belum bisa diterima sepenuhnya oleh masyarakat Indonesia. Hal ini dipengaruhi oleh beberapa faktor seperti gerakan radikal di Indonesia yang identik dengan cadar sehingga menimbulkan stigma negatif dalam masyarakat. Namun, pada perkembangan digital saat ini, media sosial sebagai media interaksi sekunder masyarakat dengan tangan terbuka menerima pilihan bercadar bagi muslimah. Di antara stigma negatif tentang cadar dalam masyarakat, justru tren cadar menjadi sebuah hal yang lumrah di media sosial Instagram. Fokus penelitian ini adalah bagaimana proses interaksi sosial perempuan bercadar dengan masyarakat maya yang aktif menggunakan media sosial Instagram. Metode yang digunakan adalah kualitatif deskriptif dengan pendekatan fenomenologi. Metode pengumpulan data menggunakan wawancara dan observasi tidak langsung. Kesimpulan dari penelitian ini adalah interaksi sosial yang terjadi media sosial berbeda dengan interaksi sosial yang terjadi pada masyarakat sosial sebenarnya, namun tetap dikatakan sebagai interaksi sosial. Interaksi sosial yang dilakukan perempuan bercadar di media sosial Instagram dalam bentuk akomodasi toleran sehingga bersifat menghindari suatu perselisihan.
\end{abstract}

Kata Kunci: Perempuan Bercadar, Media Sosial, Instagram, Interaksi Sosial 


\section{Pendahuluan}

Internet yang dulu hanya menjadi media sebatas pemberi informasi bagi masyarakat, kini sudah bertransformasi menjadi kehidupan sekunder dengan munculnya media sosial. Kini tidak hanya tatap muka langsung dengan individu lain, namun komunikasi lewat sosial media menjadi hal yang lumrah, bahkan menjadi pilihan utama sebagai media komunikasi yang bersifat lebih fleksibel. Nasrullah (2014) mendefinisikan internet sebagai komunikasi yang terjadi karena ada koneksi perangkat komputer dengan perangkat komputer yang lain atau menghubungkan komputer secara global.

Utamanya adalah media sosial saat ini, Nasrullah (2017) mendefinisikan media sosial adalah medium di internet yang memungkinkan pengguna merepresentasikan dirinya maupun berinteraksi, bekerjasama, berbagi, berkomunikasi dengan pengguana lain, dan membentuk ikatan sosial secara virtual.

Media sosial saat ini dalam perkembangannya menjadi media untuk berinteraksi antar individu. Soekanto dalam bukunya menjelaskan lebih dalam mengenai proses interaksi sosial. Apabila dua orang bertemu, interaksi sosial dimulai pada saat itu. Walaupun orang-orang yang bertemu muka tersebut tidak saling berbicara atau tidak saling menukar tanda-tanda, interaksi sosial telah terjadi, karena masing-masing sadar akan adanya pihak lain yang menyebabkan perubahan-perubahan dalam perasaan maupun syaraf orang-orang yang bersangkutan, yang disebabkan oleh misalnya bau keringat, minyak wangi, suara berjalan dan sebagainya (2012).

Interaksi sosial yang akan penulis bahas dalam jurnal ini adalah interaksi sosial perempuan bercadar di media sosial Instagram. Menurut jurnal yang ditulis oleh Perdana, Christin dan Malau, Instagram merupakan sebuah media sosial yang bergerak di bidang visual, yang memungkinkan penggunanya berbagi foto maupun video kepada orang lain. Instagram sendiri memberikan banyak kemudahan bagi para penggunanya untuk mengeksplorasi keberadaan media sosial tersebut (2016).

Keberadaan perempuan bercadar masih belum dapat diterima sepenuhnya oleh masyarakat Indonesia. Hal ini kurang lebih dipengaruhi oleh perbedaan pendapat tentang bercadar, juga beberapa gerakan radikal yang terjadi di Indonesia beberapa tahun belakangan serta diidentikkan dengan perempuan bercadar sehingga menggiring stigma masyarakat bahwa semua perempuan bercadar adalah sebuah tindakan yang patut dicurigai. Ditambah dengan anggapan masyarakat bahwa alasan dibalik penggunaan cadar oleh muslimah adalah keengganan mereka untuk bersosialisasi dengan masyarakat, Sadli dalam Amanda dan Mardianto (2017). Ratri dalam Rahman dan Syafiq (2017) menyatakan bahwa eksklusivitas dan ketertutupan komunitas cadar dapat menghambat proses sosialisasi. Salah satu faktor penting dalam pembentukan persepsi interpersonal adalah petunjuk wajah. Berbagai petunjuk nonverbal termasuk ekspresi wajah penting diketahui dalam suatu komunikasi yang akrab karena dapat menginformasikan perasaan atau emosi pihak yang terlibat dalam komunikasi.

Namun bagai langit yang terbelah, media sosial sebagai kehidupan sekunder masyarakat saat ini khususnya Instagram, menjadi gerbang pembuka utama yang dengan tangan terbuka menerima perempuan dengan cadar, yang bahkan memiliki pengikut dalam jumlah ribuan. Warganet sebagai sebutan masyarakat dalam dunia maya, merupakan cerminan dari sisi masyarakat yang menerima kehadiran perempuan bercadar di dalam media sosial dan melakukan interaksi sosial secara masif. Penulis tertarik untuk mengetahui penerimaan perempuan bercadar, melalui interaksi sosial 
yang berlangsung antara perempuan bercadar sendiri dengan masyarakat media sosial di Instagram dalam hal ini warganet.

Soekanto (2012) juga menjelaskan proses interaksi sosial dalam dua proses:

1) Proses-proses asosiatif yang terdiri dari kerja sama merupakan bentuk interaksi sosial yang pokok, kerja sama dimaksudkan sebagai suatu usaha bersama antara orang perorangan atau kelompok manusia untuk mencapai suatu atau beberapa tujuan bersama dan akomodasi sebagai suatu proses usaha-usaha manusia untuk meredakan suatu pertentangan yaitu usaha-usaha untuk mencapai kestabilan. Akomodasi sendiri terdiri dari beberapa bentuk antara lain: Coercion, Compromise, Arbitration, Meditation, Conciliation, Toleration, Stalemate dan Adjudication.

2) Proses-proses disosiatif yang terdiri dari persaingan dimana individu atau kelompok-kelompok manusia yang bersaing mencari keuntungan, melalui bidang-bidang kehidupan yang pada suatu masa tertentu menjadi pusat perhatian umum, dengan cara menarik perhatian publik atau dengan mempertajam prasangka yang telah ada tanpa mempergunakan ancaman atau kekerasan dan Kontravensi yang merupakan suatu bentuk proses sosial yang berada antara persaingan dan pertentangan atau pertikaian.

\section{Metode Penelitian}

Penelitian ini menggunakan metode kualitatif deskriptif dengan penjaringan data fenomenologi, Sugiyono (2011) mendefinisikan metode penelitian kualitatif adalah metode penelitian yang berlandaskan pada kondisi obyek yang alamiah, (sebagai lawnnya eksperimen) dimana peneliti adalah sebagai instrumen kunci, pengambilan sampel sumber data dilakukan secara purposive dan snowball, teknik pengumpulan data dengan triangulasi (gabungan), analisis data bersifat induktif/kualitatif, dan hasil penelitian lebih menekankan makna daripada generalisasi.

Penggunaan metode kualitatif dengan pendekatan deskriptif dianggap mampu membantu penulis untuk memperoleh tujuan dari penelitian ini. Karena penelitian kualitatif dianggap bukan kajian objek yang bersifat mekanistis (hukum yang pasti dan tepat) layaknya objek ilmu alam, tidak semua perilaku sosial dalam masyarakat dapat dikuantitatifkan karena persepsi setiap individu yang tergantung pada nilai budaya dan pengalaman.

Dalam penelitian ini, penulis menggunakan metode penelitian kualitatif dengan pendekatan fenomenologi. Polkinghorne dalam Herdiansyah (2011) mendefinisikan fenomenologi sebagai sebuah studi untuk memberikan gambaran tentang arti dari pengalaman-pengalaman beberapa individu mengenai suatu konsep tertentu. Gunawan (2014) mendefinisikan fenomenologi berupaya untuk memahami makna yang sesungguhnya atas suatu pengalaman dan menekankan pada kesadaran yang disengaja (intentionallity of consciousness) atas pengalaman, karena pengalaman mengandung penampilan keluar dan kesadaran di dalam, yang berbasis pada ingatan, gambaran dan makna.

Bungin dalam bukunya menjelaskan bahwa subjek adalah informan penelitian yang memahami informasi objek penelitian sebagai pelaku maupun orang lain yang memahami objek penelitian (2011). Maka dari penjabaran di atas, subjek penelitian dalam penelitian ini adalah perempuan bercadar yang aktif menggunakan media sosial Instagram. Masih dalam buku yang sama, Bungin menjelaskan bahwa objek adalah 
sasaran penelitian yang tak tergantung pada judul dan topik penelitian, tetapi secara konkret tergambarkan dalam rumusan masalah penelitian. Pada penelitian ini yang menjadi objek penelitian adalah interaksi sosial di media sosial Instagram.

Metode pengumpulan data pada penelitian ini menggunakan teknik wawancara mendalam terhadap tiga informan perempuan bercadar yang aktif menggunakan media sosial Instagram, dengan jumlah pengikut akun masing-masing, Bella Chaterina sebanyak 2.121 pengikut, Devi Purnama Sari sebanyak 41.100 pengikut, serta Chory Puja Abdi Nur sebanyak 18.500 pengikut. Selain itu, peneliti juga melakukan wawancara kepada tiga orang pengikut akun yang berbeda dari akun Instagram key informan dan salah seorang pengamat media sosial yaitu Nukman Luthfi sebagai metode keabsahan data yang diperoleh.

\section{Hasil Temuan dan Diskusi}

Berdasarkan hasil penelitian yang telah dilakukan, penulis menemukan bahwa penggunaan media sosial Instagram pada perempuan bercadar memiliki alasan yang sama dengan pengguna Instagram lain. Instagram pada awalnya digunakan untuk melakukan interaksi sosial dengan masyarakat maya atau pengguna media sosial Instagram lain. Selanjutnya key informan memanfaatkan media sosial Instagram sebagai media untuk berbisnis, baik bisnis online milik sendiri ataupun untuk menjaring tawaran endorsement dari pengguna bisnis online Instagram lainnya (wawancara dengan ketiga key informan pada waktu dan tempat yang berbeda).

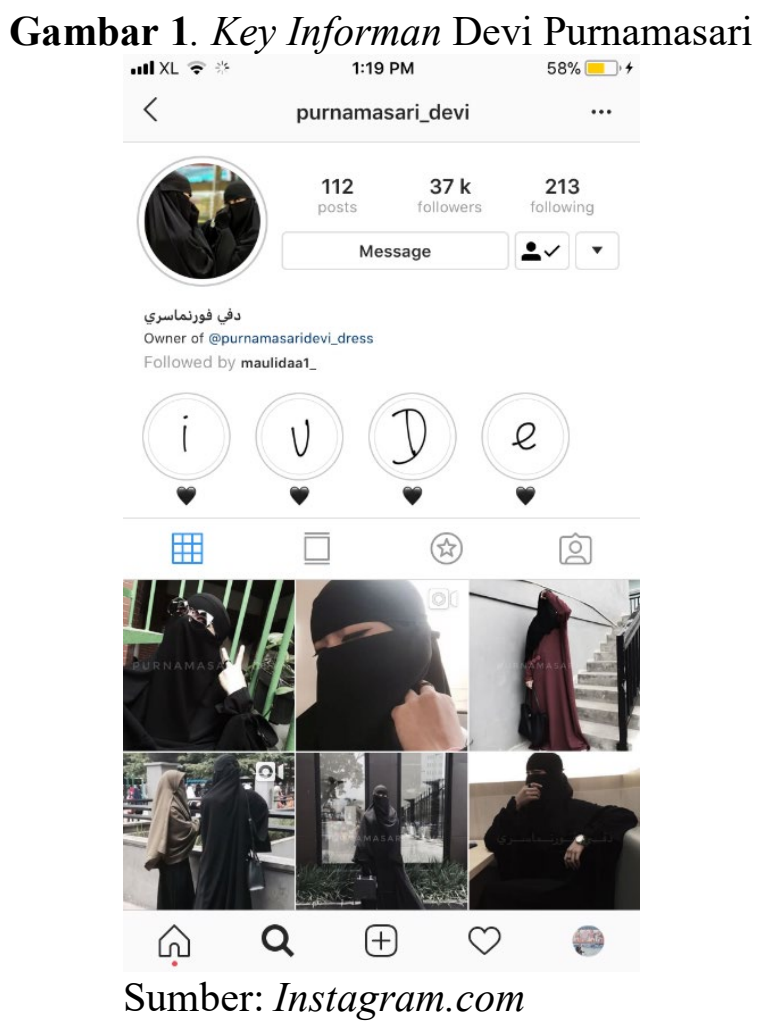

Selain itu, penulis menemukan bahwa masing-masing key informan memiliki latar belakang yang berbeda dalam memilih media sosial Instagram sebagai media interaksi sosial, dalam wawancara peneliti dengan key infroman Chory Puja Abdi Nur 
menyatakan bahwa lingkungan pertemanan sekitarnya lebih banyak menggunakan media sosial Instagram, dibandingkan media sosial lain.

Sedangkan Bella mengatakan bahwa selain untuk membagikan literasi positif mengeni kajian agama kepada pengguna Instagram lain, Instagram juga dianggap Bella sebagai media sosial yang sarat dengan informasi positif seputar tausiyah agama jika digunakan dengan bijak dan sesuai dengan yang diinginkan (wawancara dengan Bella Chaterina tanggal 14 Oktober 2018 pukul 17.35 WIB).

Hasil diskusi dari pengumpulan data yang diperoleh menyatakan bahwa, peran media sosial bagi perempuan bercadar saat ini telah menjadi sebuah kebutuhan pokok yang bahkan telah disandingkan dengan kebutuhan pokok seperti, sandang, pangan dan papan. Kehidupan perkotaan yang tidak lepas dari mobilisasi yang cepat juga memengaruhi kebutuhan terhadap ponsel pintar yang terhubung langsung dengan internet. Media sosial kini telah menjadi kehidupan sekunder masyarakat sebagai wadah untuk melakukan interaksi sosial dengan masyarakat lainnya. Hal tersebut juga berlaku pada perempuan bercadar sebagai masyarakat yang ikut menggunakan media sosial Instagram, perempuan bercadar di balik anggapan selalu menjaga ekskluisivitasnya tetap mengalami terpaan dari pengaruh media sosial dalam kehidupan sehari-hari.

Interaksi sosial yang terjadi dalam dunia maya tidak terdapat kontak badaniah di dalamnya, namun tetap dapat dikategorikan sebagai interaksi sosial jika masingmasing orang sadar terhadap keberadaan individu lain yang mengirimkan pesan. Seperti yang terjadi pada dunia maya khususnya dalam penelitian ini adalah media sosial Instagram. Setiap pengguna Instagram mengirimkan pancingan interaksi baik berupa foto maupun video dan pengguna lain yang merespon balik interaksi tersebut, maka terjadilah interaksi sosial. Hal ini karena masing-masing individu menyadari keberadaan individu lain dan melakukan interaksi sosial di dalamnya.

Penulis mendapatkan fakta di lapangan bahwa ketiga key informan peneliti dalam interaksinya di Instagram, sering mengunggah baik dalam bentuk foto, video maupun snapgram, sedangkan fitur live pada Instagram jarang dilakukan. Seperti wawancara yang telah dilakukan dengan key informan Devi bahwa sering menggunakan fitur untuk mengunggah foto. Key informan lain Bella menyatakan lebih sering menggunakan fitur snapgram dalam interaksi. Berdasarkan observasi yang juga telah dilakukan pada ketiga akun Instagram dari key informan, peneliti mendapatkan bahwa unggahan yang dilakukan key informan dalam melakukan interaksi bukan hanya seputar tausiyah agama, namun juga unggahan mengenai kegiatan sehari-hari yang menampakkan refleksi diri sendiri seperti potret atau video diri sendiri.

Hal ini tentu saja menjadi sebuah tanda tanya besar, perempuan bercadar yang selama ini dianggap sangat menjaga eksklusivitas cadarnya dalam masyarakat sosial, namun di media sosial justru mereka seperti pengguna Instagram lain, kerap menggunggah potret diri. Permasalahan ini dijawab oleh pakar media sosial Nukman Luthfi. Nukman menyatakan bahwa setiap individu baik bercadar ataupun tidak, yang menggunakan media sosial dengan tujuan bersosialisasi atau melakukan interaksi dengan pengguna lain, maka akan mengalami satu tahapan ketika selalu berusaha untuk memperkenalkan dirinya di depan orang banyak. Hal tersebut menyebabkan setiap individu yang menggunakan media sosial pasti akan berusaha memperkenalkan dirinya kepada pengguna lain lewat refleksi diri seperti unggahan potret diri, unggahan tersebut diharapkan dapat membuat pengguna lain mengenali dirinya. Pada tahapan selanjutnya, pengguna tersebut tidak akan lagi berbicara banyak tentang siapa dirinya namun akan membicarakan lingkungan sekitarnya seperti lingkungan keluarga, 
pertemanan, pendidikan dan lain-lain. Namun, Nukman Luthfi menambahkan bahwa kebanyakan pengguna media sosial terlalu lama berrada pada tahap pertama sehingga terkesan selalu membuat unggahan yang berfokus pada dirinya sendiri.

Selanjutnya, bukan tidak banyak pengikut pada Instagram key informan yang berkomentar langsung pada unggahan berupa potret diri key informan, ataupun unggahan seputar tausiyah agama yang memiliki perbedaan pendapat dengan pendapat pengikutnya di Instagram. Namun, meskipun mendapat komentar negatif terkait unggahan yang telah ditampilkan, key informan perempuan bercadar memilih untuk diam ketimbang membalas komentar tersebut untuk menghindari perselisihan di media sosial. Maka, interaksi sosial yang terjadi pada perempuan bercadar di media sosial Instagram, sesuai dengan wawancara dan observasi yang telah peneliti lakukan, merupakan interaksi sosial dalam proses asosiatif dengan bentuk akomodasi. Akomodasi adalah suatu proses usaha-usaha manusia untuk meredakan suatu pertentangan yaitu usaha-usaha untuk mencapai kestabilan, Soekanto (2012). Akomodasi sebagai interaksi sosial juga memiliki berbagai macam bentuk, dalam hal ini interaksi sosial yang terjadi adalah dalam bentuk toleransi. Key informan lebih memilih diam untuk menghindari perselisihan serta mencapai kestabilan hubungan sosial yang dinamis, juga lebih memilih untuk berpikir menolerir sikap dan komentar negatif mengenai unggahan dirinya dengan beranggapan bahwa tidak semua orang dapat menerima pendapatnya.

Hal ini juga diperkuat oleh pernyataan ketiga akun pengikut Instagram dari key informan. Masing-masing informan menyatakan bahwa lebih sering tidak berkomentar pada unggahan-unggahan key informan perempuan bercadar yang memiliki perbedaan pendapat dengan pendapatnya sendiri, karena sangat menghindari perdebatan yang dapat terjadi di media sosial Instagram.

Pada penelitian ini penulis juga menemukan sebuah temuan yang dianggap mendesak untuk dilakukan penelitian lanjutan. Peneliti mendapati perempuan bercadar kerap mendapat kekerasan verbal di media sosial dalam bentuk komentar negatif karena identitas cadarnya. Kekerasan tersebut bahkan berlanjut hingga ke kehidupan sosial sebenarnya yang berupa kekerasan non-verbal. Kekerasan verbal yang dialami di media sosial oleh salah satu key informan perempuan bercadar berlanjut hingga ke kehidupan sosial sebenarnya. Devi, yang pada saat itu sedang melakukan siaran langsung di Instagram menyebutkan posisi dimana ia berada dan dihampiri langsung oleh individu yang telah melakukan kekerasan verbal terhadap dirinya dalam siaran langung Instagram, serta mendapatkan kekerasan non-verbal secara langsung berupa tatapan intimidasi dari individu tersebut.

Perlakuan tersebut menimbulkan rasa takut dan trauma pada perempuan bercadar. Ini menimbulkan keengganan untuk membuka jalur interaksi dengan para pengikutnya di Instagram. Seperti yang dilakukan oleh Devi, dimana dia lebih dulu membentengi diri agar tidak mendapatkan kekerasan verbal berupa komentar negatif dengan menutup kolom komentar pada beberapa unggahannya.

\section{Simpulan}

Media sosial Instagram digunakan untuk berinteraksi dan berbisnis oleh perempuan bercadar. Instagram pun dipilih sebagai sarana berinteraksi oleh perempuan bercadar karena penggunaan yang lebih mudah, lingkungan pertemanan yang lebih banyak menggunakan Instagram dan mengandung lebih banyak manfaat jika dipergunakan sebagai mana mestinya. 
Fokus dari penelitian ini yang meneliti bentuk interaksi sosial yang terjadi pada perempuan bercadar di Instagram berbeda dengan interaksi sosial yang terjadi pada masyarakat sosial sebenarnya, namun tetap disebut sebagai interaksi sosial. Interaksi sosial perempuan bercadar yang terjadi di media sosial Instagram dalam bentuk asosiatif toleran. Perempuan bercadar sangat menghindari perdebatan mengenai perbedaan pendapat yang terjadi terkait dengan unggahan yang di eksposnya, menganggap bahwa tidak semua orang dapat berpendapat atau berpikiran sama dengan dirinya. Juga adanya temuan baru yang peneliti dapatkan mengenai kekerasan verbal yang dialami oleh perempuan bercadar di media sosial Instagram, hingga berlanjut pada masyarakat sosial sebenarnya.

\section{Ucapan Terima Kasih}

Ucapan terima kasih diberikan kepada Fakultas Ilmu Komunikasi Tarumanagara keluarga, sahabat dan juga para narasumber yaitu: Devi Purnamasari, Bella Chaterina, Chory Puja Abdi Nur dan Nukman Luthfi yang telah meluangkan waktunya untuk melakukan wawancara dengan penulis, serta berbagai pihak yang telah membantu kelancaran penelitian ini.

\section{Daftar Pustaka}

Al Batawi, \& Zahrudin Ali. (2012). 1500 pantun betawi. Jakarta: Nus Printng.

Amanda, R. (2017). Hubungan antar prasangka masyarakat terhadap muslimah bercadar dengan jarak sosial. Jurnal RAP, 5(1), 72-81.m Nasrullah, Rulli. (2014).

Bungin, Burhan. (2011). Penelitian kualitatif komunikasi, ekonomi, kebijakan publik, dan ilmu sosial dan lainnya. Jakarta: Kencana Prenada Media Group.

Gunawan, Imam. (2014). Metode penelitian kualitatif: teori dan praktik. Jakarta: PT Bumi Aksara.

Herdiansyah, Haris. (2011). Metode penelitian kualitatif untuk ilmu-ilmu sosial. Jakarta: Salemba Humanika.

Nasrullah, Rulli. (2017). Media sosial perspektif komunikasi, budaya, dan sosioteknologi. Bandung: Simbiosa Rekatama Media.

Perdana, R., Christin, M., \& Malau, R. (2016). Citra kawasan strategis nasional cekungan Bandung melalui instagram pada pengguna hashtag \#explorebandung. Jurnal Kajian Komunikasi, 4(2), 185-198. doi: http://dx.doi.org/10.24198/jkk.v4i2.7951

Rahman, A. F., \& Syafiq, M. (2017). Motivasi, stigma dan coping stigma pada perempuan bercadar. Jurnal Psikologi Teori dan Terapan, 7(2), 103-115.

Soekanto, Soerjono. (2012). Sosiologi suatu pengantar. Jakarta: PT RajaGrafindo Persada.

Sugiyono. (2011). Metode penelitian pendidikan (pendekatan kuantitatif, kualitatif, dan R\&D). Bandung: Alfabeta, cv.

Nasrullah, Rulli. (2016). Teori dan riset media siber (Cybermedia) (Edisi 1). Jakarta: Prenadamedia Grup. 